Western North American Naturalist 67(4), (C) 2007, pp. 618-621

\title{
HAY PILES OF THE MOUNTAIN BEAVER (APLODONTIA RUFA) DELAY PLANT DECOMPOSITION
}

\author{
Richard Karban $^{1,2}$, Claire Karban ${ }^{1}$, and Jesse Karban ${ }^{1}$
}

\begin{abstract}
Mountain beavers cache plants in neat piles above the ground near the entrances to their underground burrows, although the purpose of these hay piles remains controversial. We tested the hypothesis that drying plants in piles above ground may slow decay when the plants are stored underground. Predried plants and undried controls were placed in abandoned burrows. Plants that had been predried retained more green and decayed more slowly than undried controls. This experimental test supports the hypothesis that haying may extend the time during which plants are useful to mountain beavers.
\end{abstract}

Key words: Aplodontia rufa, mountain beaver, cache, drying, hay pile, Sierra Nevada, California.

Several food-hoarding mammals, including mountain beavers (Aplodontia rufa) and pikas, (Ochotona princeps) cut and cache their food as hay piles. The significance of these hay piles remains uncertain, and several hypotheses have been proposed to explain them. Hay piles were thought by some researchers to provide dry, long-term food for the mountain beavers (Bretherton 1895, Morrison 1936). Others suggested that hay piles are not eaten, but supply dry bedding or nesting material (Camp 1918, Parker 1952). Still others questioned whether hay piles could be used for food or nesting material, as they never dry completely (Voth 1968). Hay piles of pikas have received more attention than those of mountain beavers. For pikas, food placed in hay piles during the summer is thought to allow plant toxins to degrade before the food is eaten in winter (Dearing 1997).

Mountain beavers harvest and store a wide variety of plant species, primarily at the end of summer (Lum 1878, Merriam 1896, Seton 1929, Carraway and Verts 1993). They arrange the plants in neat piles on the ground surface near the entrance to their burrows. Plants found in excavated feeding chambers are the same species found in hay piles (Voth 1968). Food storage is likely a problem for mountain beavers. Much of the vegetation in excavated feeding chambers is "long stored, partly eaten pieces, many decaying, mixed on the floor with wet soil" (Voth 1968:146). Indeed, Voth estimated that at least $60 \%$ of harvested food cannot be ingested because it is too decayed. If so, then taking measures to slow the rate of decay could be advantageous to mountain beavers. We tested the hypothesis that drying plants in piles above ground may slow decay when the plants are stored underground. We placed plants that had been dried and plants that were freshly cut into abandoned burrows and observed their fates.

We observed 2 populations of mountain beavers at Valentine Eastern Sierra Reserve near Mammoth Lakes, California, along Bear Creek $\left(37^{\circ} 37.7^{\prime} \mathrm{N}, 118^{\circ} 59.5^{\prime} \mathrm{W}\right)$ and along Juniper Spring $\left(37^{\circ} 37.7^{\prime} \mathrm{N}, 118^{\circ} 59.7^{\prime} \mathrm{W}\right)$. On a daily basis, we visited a total of 40 hay piles used by mountain beavers during the summers of 20012003. Hay piles often persisted throughout a season, although stems within a pile disappeared much more frequently than entire piles. We recorded the number, condition, and species of all plants in each pile. We also recorded which cut plant pieces disappeared from the piles and which plants we observed at the entrance or interior of each burrow.

To mimic drying conditions of naturally collected plants, we collected 10 stalks of false Solomon's seal (Smilacina stellata) from Bear Creek and 10 stalks of corn lily (Veratrum californicum) from Juniper Springs on 1 July 2002, during the time when hay piles were common at the study sites. Each stalk was placed in a plastic mesh bag of Dupont Vexar (mesh size $\sim 5 \mathrm{~mm}$ ). The bags allowed us to move the 
stalks and allowed air and water to contact the cut plant material. The 10 stalks of each plant species were dried for 7 days by placing them individually on the ground along Bear Creek. Bags were then placed individually into naturally occurring $A$. rufa burrows that had been abandoned during the previous year. (The population along Bear Creek has been in decline.) We reached into the burrows and classified them as either wet (10 burrows with moisture to the touch at the bottom) or dry (10 burrows with no moisture to the touch). Because the burrows were wider than the bags, the bags were inserted approximately $50 \mathrm{~cm}$ into the underground burrows by hand with no additional digging. On 8 July 2002 , 10 additional wet stalks of each plant species were cut, bagged, and placed in the abandoned burrows without drying. Each bag was placed in a different burrow and all bags were retrieved from the burrows after 16 days. We photographed each plant stalk at the end of the experiment and analyzed the amount of green color present in each using the RGB color mode in Adobe Photoshop 6.0. We recorded the value of green that remained in the foliage on each stalk, where 0 is black and 255 is pure green. Possible effects of our treatments on the green values were assessed using ANOVA in JMP statistical software (SAS Institute, Cary, NC).

Because the burrow system along Bear Creek where this experiment was conducted was not being actively used, we questioned whether conditions in the abandoned burrows were similar to those in an active burrow system along Juniper Springs. We sampled soil from the floors of 14 burrows along Bear Creek and 14 burrows along Juniper Springs on 30 June 2006. Approximately $30 \mathrm{~mL}$ of soil was collected in a plastic cup at a distance of $50 \mathrm{~cm}$ from the burrow entrance for each sample. The soil was weighed wet and weighed again after being dried at $50^{\circ} \mathrm{C}$ for 14 days. Soil water content was calculated as (wet weight - dry weight) / wet weight. We evaluated possible differences in mean water content of soils from these 2 sites using 1-way ANOVA (JMP).

Individuals from 1 population of A. rufa along Bear Creek primarily cut shoots of false Solomon's seal, lupine (Lupinus polyphyllus), quaking aspen (Populus tremuloides), and mountain alder (Alnus incana). Individuals from a 2nd population along Juniper Springs primar- ily cut shoots of corn lily and willow (Salix spp). These food plants have been reported in the literature for other A. rufa populations (Steele 1989, Stagg 1997). We observed that hay piles of cut plants remained for $<1$ week above ground, until they were fully wilted but not dried, based on plant turgor and color. At least some of the vegetation in piles was carried into underground burrows, based on pieces that were visible near the burrow entrance and within the tunnels. We observed no hay piles drying for longer periods of time and no fully dried plant material above ground near the active burrows.

Both sites had burrows that spanned a wide range of soil water conditions. Water content of soil from burrows ranged from $9 \%$ to $78 \%$ at the experimental Bear Creek site and from $27 \%$ to $89 \%$ at the active Juniper Springs site. We were unable to detect a significant difference in mean water content of soils within burrows at these 2 locations. Average soil water content was $0.36 \pm 0.05(s)$ for Bear Creek and $0.48 \pm 0.05$ for Juniper Springs $\left(F_{1,26}=3.16, P=0.09\right)$. Many of the burrows at both sites had water flowing along the floor during the spring and early summer. These observations are consistent with those of previous workers who noticed water flowing through active burrows (Lum 1878, Seton 1929). Hot, dry conditions present a more serious problem for mountain beavers than do cool, wet conditions (Johnson 1971), although wet conditions may make food storage difficult.

Air-drying of vegetation before placement in burrows produced dramatic and consistent effects. For both plant species, predried material remained green 16 days later than undried material, which disintegrated and became dark. Analysis of the amount of green color remaining after placement of vegetation in the burrows indicated that the plant species responded differently. Corn lily from both the dried and the undried treatments completely disintegrated in wet burrows (no photograph). In drier burrows (without water on the bottom), predried corn lily was intact and green with some white fungus, whereas undried corn lily was black and largely disintegrated (Fig. 1A). This result was supported by an analysis of the amount of green that remained in the foliage. Average green value for predried plants was $96.3 \pm 8.4(s)$ and $7.6 \pm 1.7$ for undried plants $\left(F_{1,8}=106.7, P<0.001\right)$. False Solomon's seal that was predried aboveground had some white 

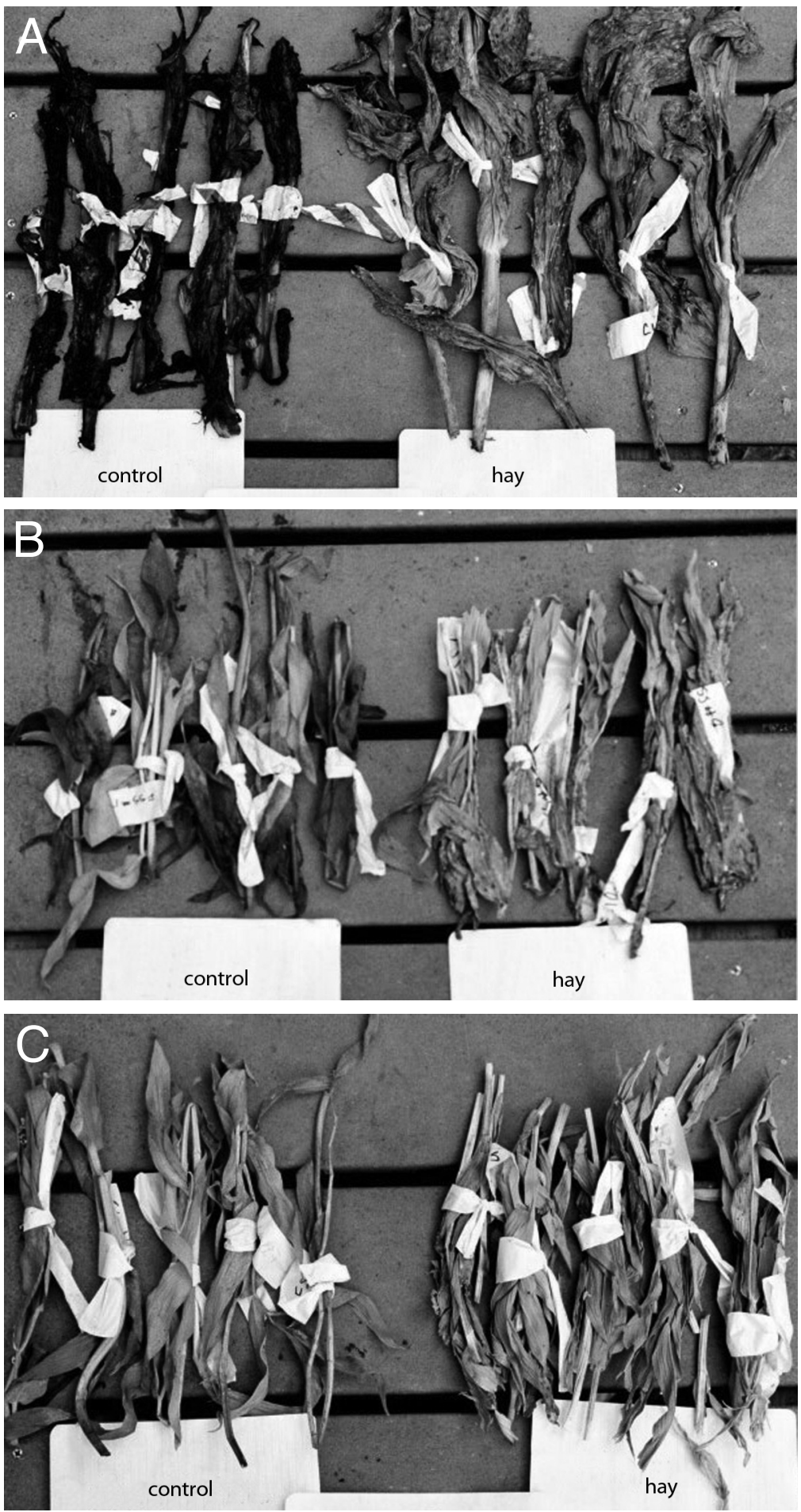

Fig. 1. Samples of plant material that had been placed for 16 days in burrows of Aplodontia rufa. Plant material was either predried for 7 days before placement (hay treatment) or not dried (control treatment). Each bundle represents an independent replicate. A, Corn lily placed in drier burrows. B, False Solomon's seal placed in drier burrows. C, False Solomon's seal placed in wetter burrows. 
mold but was mostly green and intact, while undried material was dark and disintegrated from both dry (Fig. 1B) and wet (Fig. 1C) burrows. This was also reflected in the values of green color remaining in the foliage. Average green value was $138.8 \pm 4.7(s)$ for predried plants and $97.4 \pm 10.0$ for undried plants $\left(F_{1,18}\right.$ $=14.0, P=0.002$ ).

In this experiment, we attempted to simulate the cutting, drying, and underground placement of plants by mountain beavers. Plants that we dried disintegrated far less in abandoned $A$. rufa burrows than did undried plants. These experimental results lend support to the hypothesis that the behavior of cutting and storing plants above ground may increase the useful lifespan of plant material brought into the burrow by delaying plant decomposition by microbes. Our experimental results confirm earlier observations that haying is not sufficient to prevent decay, although haying may extend the time during which plants are useful to mountain beavers. This experiment only considered $1 \mathrm{hy}-$ pothesis. Hay piles also may have other functions such as allowing individuals to adjust their water intake or providing a secure food source when foraging above ground would be dangerous because of predators or unfavorable climatic conditions.

This research was conducted at the University of California Valentine Eastern Sierra Reserve. We thank D. Dawson for facilitating our work and L. Dawson for providing useful natural history about A. rufa at this site. R. Hamilton helped with our experiment and M. Huntzinger, L. Yang, and several reviewers improved the manuscript.

\section{Literature Cited}

Bretherton, B.J. 1895. Some Oregon mammals: the mountain boomer. Oregon Naturalist 2:123-125.

CAMP, C.L. 1918. Excavations of burrows of the rodent Aplodontia rufa, with observations on the habits of the animal. University of California Publications in Zoology 17:517-536.

Carraway, L.N, and B.J. Verts. 1993. Aplodontia rufa. Mammalian Species 431:1-10.

Dearing, M.D. 1997. The manipulation of plant toxins by a food-hoarding herbivore, Ochotona princeps. Ecology 78:774-781.

JoHnson, S.R. 1971. The thermal regulation, microclimate, and distribution of the mountain beaver, Aplodontia rufa pacifica Merriam. Doctoral dissertation, Oregon State University, Corvallis.

Lum, S.K. 1878. The sewellel or show'tl. American Naturalist 12:10-13.

Merriam, C.H. 1896. Description of a new species of Aplodontia from California. Annals of the New York Academy of Sciences 3:312-328.

Morrison, F.B. 1936. Feeds and feeding. 20th edition. Morrison, Ithaca, NY.

Parker, H.C. 1952. Mammals of Yosemite National Park. Yosemite Nature Notes 31(6):52-105.

SETON, E.T. 1929. Lives of game animals. Doubleday, Garden City, NY. 4(2):441-949.

STAGG, R.J. 1997. Summer home range size of the eastern cascade mountain beaver (Aplodontia rufa rainieri) in relation to availability of preferred food. Master's thesis, Central Washington University, Ellensburg.

STEELE, D.T. 1989. An ecological survey of endemic mountain beavers (Aplodontia rufa) in California, 1979-83. State of California, Department of Fish and Game, Wildlife Management Division, Administrative Report \#89-1. 58 pp.

Voth, E.H. 1968. Food habits of the Pacific mountain beaver, Aplondontia rufa pacifica Merriam. Doctoral dissertation, Oregon State University, Corvallis.

Received 26 October 2006 Accepted 26 June 2007 